\title{
The comparison between the walls properties from brick and reinforced concrete of Russian orthodox temple buildings
}

\author{
Ivan Saltykov ${ }^{1,}{ }^{*}$ and Maria Bovsunovskaya ${ }^{1}$ \\ ${ }^{1}$ Moscow State University of Civil Engineering, Yaroslavskoyeshosse, 26, Moscow, 129337, Russia
}

\begin{abstract}
The orthodox temple buildings have the wide range of architectural and construction designs, and the same time, their erection and projecting process are under the influence of strict orthodox canons. The exterior wall is one of the main structures of orthodox church building. For today, the traditional brick and contemporary modern material, reinforced concrete, are the mostly wide spread materials in orthodox churches buildings; the mix of these two materials is also possible. The issue is concerned with the analyses architectural and construction requirements to external temple walls and to their features comparison in both cases: for traditional canonical and contemporary designs. The strength, thermal and technical, acoustical, architectural and aesthetical, economical properties of walls are compared for these two construction variants. The scope of this issue contains the instance of approximate strength calculation for the temple of small volume and crude data for the cost of one square meter of external wall in four specific construction designs. Comparative analysis allows choosing a more environmentally friendly material and improving the energy efficiency of the facility.
\end{abstract}

\section{Introduction}

Orthodox temple architecture have a wide variety of construction designs, in spite of strict requirements of orthodox canons, which were formed in more than a thousand history of Christianity in Russia. Different historical periods had a specified impact on the features of cultic orthodox buildings. Nowadays, we can see the next stage of ecclesiastical architecture evolvement with its own trends. The gradual transition from traditional architectural and construction solutions in churches' building to contemporary materials and technologies, sometimes with ambiguous social assessment, is one of the distinct features of recent time.

In this context, it is interesting to make a comparison between traditional and contemporary constructions of orthodox churches erecting in Russia, from the point of view strength, functional and acousticalnecessary requirements. Especially actual the project designers considerations are against the background of relatively modern temple Moscow building program, which is known as "Two Hundred Temples". The implementation of this

${ }^{*}$ Corresponding author: vincesalt@mail.ru 
program, in particular, is connected with the choice of optimum designs and source of financing for the building of congregational temples in a walking distance.

\section{Materials and Methods}

It is known in Russian construction practice, that there are five general structural systems: wall system, frame system, room unit system, structural core system and shell system. Historically formed space-planning decisions of Russian orthodox temples, which have their origin in antique basilicas, are the adequately authentic and unique objects of old architecture. So they can't be referred only to one kind of these systems. For instance, there is a combination of massive exterior bearing walls, typical for wall construction system, and the stone pillars or columns, which are specified for frame system in cultic buildings. And the same time, domes and vaults establish a building volume in a great measure and can be classified as shell constructions. Also the mobile and rapidly erected kind of temples today becomes to be in demand, some parts of their constructions is completed as separate functional volume blocks. Nevertheless, churches walls and their varieties as stone pillars continue to play the main bearing and enclosure role in historically formed architectural image of orthodox churches.

Exterior bearing walls should have a property of taking gravity load,weight of upper structures and working load for transmission them on foundations. Generally, wall structures work as avertical loaded elements, but sometimes, they have another one function: the capacity to work as a bending elements, in other words, to take up lateral forces. These lateral forces usually occur in the wall structures from horizontal thrust forces in arcs, vaults and domes, in case of their resting on the walls. Wall structures also work as insulating from outdoor environment members, that remove environmental activity and provide comfortable thermal and acoustic indoor microclimate conditions in temple buildings $[1,2,3]$.

Historically, natural stone, wood and brick were the main materials for external and internal bearing walls of orthodox temples. Today, steel and concrete, especially in frame elements, are added to this traditional range of materials [4]. The buildings from natural stone, which is rather expensive and hard-to-machine materialin the most territory of Russia, and from comparatively nondurable wood are less-demand, than from brick and normal reinforced concrete. The application of reinforced concrete is a frequent event for raft, continuous and pile foundations, flat slabs, mezzanine floors and choir stalls $[5,6]$. The rapidness and constructability of concrete structures erection suggest the practicability of theirapplication separately or in combining with the brickwork in exterior walls of religious buildings, that will be described below.

Some practicing architects believe [7, 8], that the wall thickness of orthodox newly erected churches should be equal to the wall thickness of old extant architectural monuments: middle volume temple should have a wall thickness at least $900 \mathrm{~mm}$, and the wall thickness of temples with larger volume should be equal to $1200-1500 \mathrm{~mm}$. Thereat walls are accomplished from piece elements, as a rule, from ceramic bricks.However, according to contemporary practice, the thin of a wall can be substantially diminished, when the modern construction materials, such as a concrete and high-grade brick are applied. What extent of sufficiency have the old architectural canons in their technical and economical aspects?This question can be answered by the comparison of advantages and disadvantages in traditional and modern walls designs, considering the walls as bearing, enclosing, and esthetical temple architectural elements.

Walls and partitions, working only as vertical bearing elements, should have global stability from vertical load application, that structurally will influence on size relation between wall thin, $b_{w}$, and wall height, $h_{w}$. As was described earlier, wall and partition 
structures can work in bending: for instance, in case of load with a big eccentricity, slab floor rigid support, lateral load bearing, and wind load resistance. The real engineering design in this situation is rather complicated and labor-intensive, so it fall within the competence of facility design engineer and lays beyond the scope of this issue. However, this issue shows that the building demands for main overall dimensions of walls and partitions with the comparison of structure and material variants, can be taken into account due to the following construction relationships: $b_{w} / h_{w}$ should not exceed $1 / 10$ for stone material walls from natural stone, unreinforced brick working,and aerated concrete blocks, because of their low behavior in bending and tension; $b_{w} / h_{w}$ may be as high as $1 / 20-1 / 30$ for walls from reinforced concrete and reinforced working brick with high mortar grade, due to these walls high capacity to take upstretching stresses.

We can evaluate the effectiveness of stone material application after carrying out a simple approximate calculation. It's interesting to compare the weight of one long meter of a wall of the temple, which is an architectural monument, and the weight of one long meter of bearing temple wall with the same main dimensions and loads for contemporary church building, and also to compare the strip foundation width in both cases. So the effectiveness of material application in traditional or in modern structure design can be inferred by the weight of one long meter at the wall footage level.

As an actual example, we shall consider wall structures of the architectural monument of XV century - "The Descent of the Holy Spirit upon the Apostles" in the Trinity Lavra of St. Sergius in SergievPosad, Russia. The brick is a material of this temple. The considering span on fig. 1 has: a wall thickness, $b_{w}=1,3 \mathrm{~m}$ and approximate thickness of roof slab, $h_{r s}=0,27 \mathrm{~m}$; the specific weight of brick walls and roof slab, $\gamma_{w}=\gamma_{r s}=1800 \mathrm{~kg} / \mathrm{m}^{3}$. The length of span $l=1,75 \mathrm{~m}$; effective height of a wall $H_{w}=10,2 \mathrm{M}$; the parapet height $H_{\text {par }}=0,76 \mathrm{~m}$; the parapet thickness $b_{\text {par }}=0,9 \mathrm{~m}$. It is instructive to define approximately the theoretically required thickness of the wall, $b_{w . r .}$, and the width of the foundation, $b_{f r}$, and to compare them with their real values.As well, we can find out such parameters for temple walls of the same volume under the same vertical load, when the walls are maiden from reinforced concrete.

The figure 1 shows the scheme of architecture monument section view with basic dimensions of the wall. The vertical loads (total load $-P_{t o t}$ ) are approximatelygathered on 1 long meter of wall footing from dead load of the wall and summary load from the vault slab (formula 1).The imposed loads are calculated in a general way for the most pressure bearing wall fragment without any safety factors, except of snowing load, which has its estimated value according to normative codes.

$$
P_{\text {tot }}=P_{w}+P_{r s},
$$

where $P_{w}$ - the total weight of the wall fragment with the thickness of $1 \mathrm{~m}$, including parapet, which is equal to $25099 \mathrm{kgf} / \mathrm{m} ; P_{r s}$ - the weight of roof slab, including the snow load, which is equal to $583 \mathrm{kgf} / \mathrm{m}$. Thus, the total aggregative load by formula (1):

$$
P_{\text {tot }}=25099+583=25682 \mathrm{kgf} / \mathrm{m}
$$

Required minimum thickness of the wall footage, $b_{w . r .}$, because of brick behavior only on compression, can be found using the formula (2).

$$
b_{w . r .}=\frac{P_{t o t}}{\varphi R_{c o m p}^{m}},
$$

where $R_{c o m p}^{m}$ - wall material ultimate resistance to compression: $100 \mathrm{kgf} / \mathrm{cm}^{2}$ for concrete, $10 \mathrm{kgf} / \mathrm{cm}^{2}$ - for brick working; $\varphi$ - buckling coefficient, for this relationship $b_{w} / h_{w}$ can be roughly accepted near 1 . 


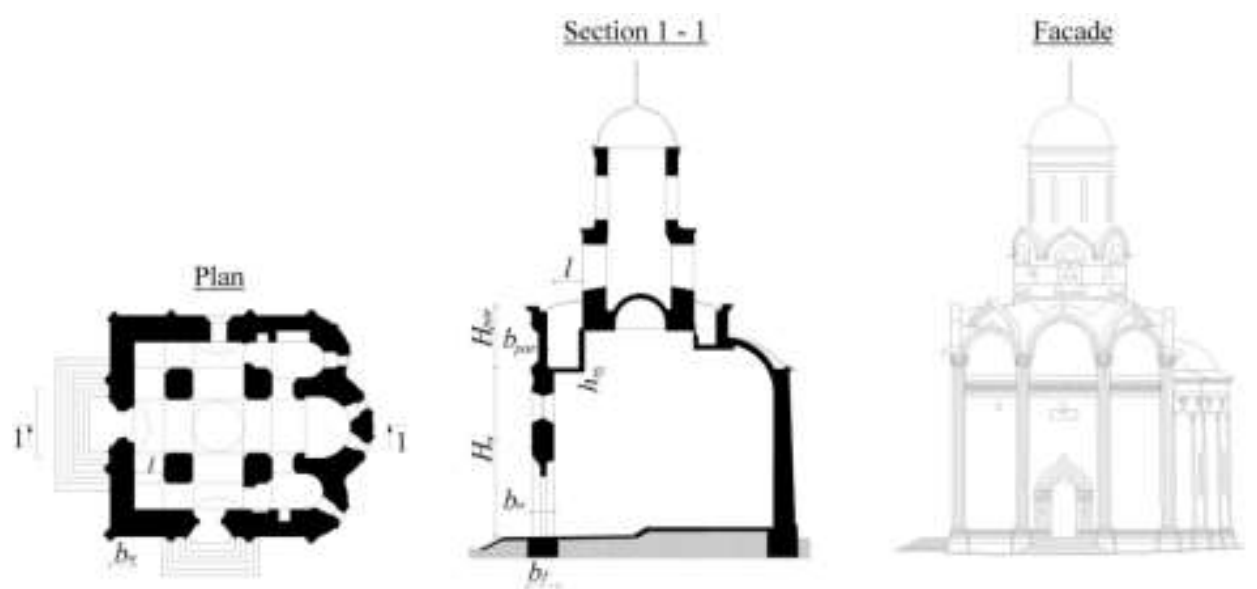

Fig. 1. Plan, section view and facade of old church - "The Descent of the Holy Spirit upon the Apostles", Sergiev Posad.

So

$$
b_{w . r .}=\frac{25682}{1 \cdot 10 \cdot 10^{4}}=0,25 \mathrm{~m}
$$

That far less, than $b_{w}$ real. Well known, approximate stability condition for unreinforced brick walls, corresponding to relationship $b_{w} / h_{w}=1 / 10$, makes thickness of the supposed brick wall, $b_{w}$, be equal to $10,2 / 10=1,02 \mathrm{~m}$, that's also less, than $b_{w}$ real.

Required foundation width, $b_{f . r .}$, should be equal by formula (3):

$$
b_{f . r .}=\frac{P_{t o t}}{R_{S}}
$$

where $R_{S}$ - earth back pressure, in other words, the maximal pressure, which soil can withstand without destruction; the middle quality soils have earth back pressure near 2 $\mathrm{kgf} / \mathrm{cm}^{2}$. Than

$$
b_{f . r .}=\frac{25682}{20000}=1,28 \mathrm{~m}
$$

that is also less than the width of real concerned rubble stone foundation, which is equal to $1,88 \mathrm{~m}$.

Contemporary reinforced concrete structures of the walls, should have the width, in average, equal to $1 / 30 \cdot H_{w}=1 / 30 \cdot 10,2=0,34 \approx 0,35 \mathrm{~m}$. Than $P_{\text {tot.rc. }}$ for reinforced concrete wall in formula (1) with the same load of the roof slab will have a value of $9590 \mathrm{kgf} / \mathrm{m}$, after the author's calculation. Thus, in this case the wall weight with its parapet will be by 62 percent less, and $P_{\text {tot.rc. }}$ in compliance with formula (1) will be equal to:

$$
P_{\text {tot.rc. }}=9590+583=10173 \mathrm{kgs} / \mathrm{m}
$$

The minimal required width for concrete wall footage, $b_{\text {w.r.r.c., }}$ which is based only on concrete compression working, can be obtained by formula (2) with $\varphi \approx 0,5$ for relationship $b_{w} / h_{w}=1 / 30$ :

$$
b_{\text {w.r.r.c. }}=\frac{10173}{0,5 \cdot 100 \cdot 10^{4}}=0,02 \mathrm{~m}
$$

That is unacceptable by practical constructionalconsiderations, but shows a high strength reserve for reinforced concrete walls.

The required foundation width, $b_{\text {f.r.r.c. }}$, should be equal by formula (3): 


$$
b_{\text {f.r.r.c. }}=\frac{10173}{20000}=0,51 \mathrm{~m}
$$

that is by 60 percent less, than the width of architectural monument church in Sergiev Posad.

Due to this approximate calculation, which is based on the regularities of structural mechanics, we can make a conclusion that the wall material changing with reinforced concretein case of the same building design, as considered architectural monument, would allow to reduce the wall weight and the bottom of foundation width nearly 40-60 percent. So this one and the others approximate calculations witness the less rational material use in bearing brick temple walls in comparison with concrete wall constructions, even without taking into consideration the lateral forces.

It is necessary to notice, that displayed above analysis of the wall work as construction and following conclusion do not depreciate theold Russian architects merits and historical value of the church "The Descent of the Holy Spirit upon the Apostles" in SergievPosad at all.

The requirements of heating loss resistance are in the second order of priority after the strength and carrying load capacity. According the Russian codes, the walls of orthodox temples should be designed only by the sanitary and hygienic requirements to enclosure structures with the indoor temperature $t_{\text {ind }}=14{ }^{\circ} \mathrm{C}$ in the central part of the temple. That means, that the required heat transmission resistance should be equal not to 3,15 or 2,7 $\mathrm{m}^{2 \circ} \mathrm{C} / \mathrm{Wt}$ like for the walls of residence and public buildings respectively, but should be nothing more than $1,21 \mathrm{~m}^{2 \circ} \mathrm{C} / \mathrm{Wt}$.

a)

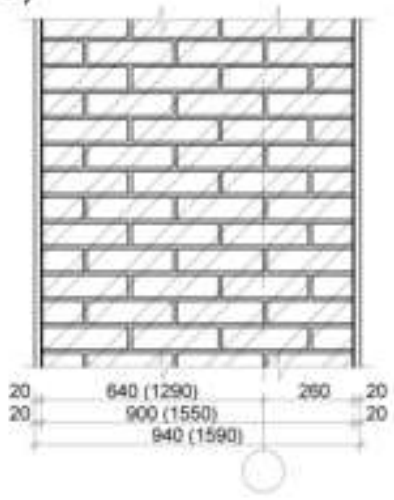

b)

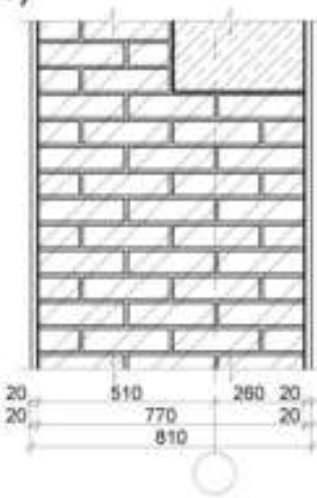

c)

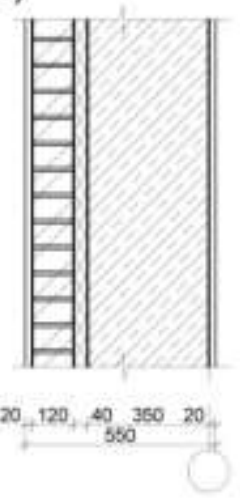

d)

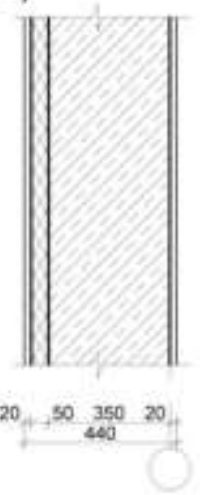

Fig. 2. The exterior walls variants of orthodox temples, which are considered in this issue: a) for traditional brick walls; b) for brick walls, which works in combination with reinforced concrete frame elements; c), d) for reinforced concrete walls in considered approximate calculation instance with outer layer from brick and plaster respectively.

And further, being performing thermo technical calculation for brick wall variant with $\lambda \approx 0,7 \mathrm{Wt} / \mathrm{m}^{\circ} \mathrm{C}$ and $1,3 \mathrm{~m}$ thickness, fig. $2 \mathrm{a}$, we obtain the total heat transmission resistance, $\mathrm{R}_{\text {h.tot }} \approx 2,0 \quad \mathrm{~m}^{2 \circ} \mathrm{C} / \mathrm{Wt}$. The reinforced concrete wall in considered instance with $\lambda \approx 2,04 \mathrm{Wt} / \mathrm{m}^{\circ} \mathrm{C}$ shows the $\mathrm{R}_{\mathrm{h} . \mathrm{tot}} \approx 0,33 \mathrm{~m}^{2 \circ} \mathrm{C} / \mathrm{Wt}$, so this structure should be protected from the cold by effective insulation with lining brick or decorative plaster,fig. $2 \mathrm{c}, \mathrm{d}$.

The three layer wall construction with effective insulation (like mineral wool and expanded polystyrene), fig. 2c, requires the insulation thickness equal to $40 \mathrm{~mm}$. In case of exterior layer from decorative plaster, fig. $2 \mathrm{~d}$, the insulation thickness should be equal near $50 \mathrm{~mm}$. The brick walls including the frame elements, fig. $2 \mathrm{~b}$, need the thickness of 770 
$\mathrm{mm}$, their $\mathrm{R}_{\mathrm{h} . t o t}$ will be near $1,26 \mathrm{~m}^{2 \circ} \mathrm{C} / \mathrm{Wt}$. Therefore, it can be said, that the brick walls of minimal thickness conform to the thermotechnical requirements.

The main problem, while insulating reinforced concrete and thin brick wallsof the temples in accordance with the orthodox architecture, is creation of outer facade surface, which is aesthetically highlighted by the composition from traditional architectural millworks, such as applied columns, pilaster-strips, arched gables, cornices, doors and window bandings, decorative frisos, blind arcades band and the other elements. It is recognized, that it may become necessary to replace effective insulation in 50-100 years, after expiration term of its service,so it can cause the complete replacement of all architectural elements from brick in case fig. $2 \mathrm{c}$ and from plastered polystyrene in case fig. $2 \mathrm{~d}$. Such construction operation is unprocessible, expensive and can provoke the full changing or even losing of original appearance of the temple.

This situation corresponds to the erection of large volume temples, but it can be accepted forsmall churches and chapels buildings in case of qualitative construction materials and deliberate design decisions for exterior layer; and in case of design documentation maintenance for further possible reconstruction under its economic assessment within the framework of all project.

The permeability to air of outer walls is the important factor from the point of view on comfortable inner thermophysical conditions in orthodox temple buildings.It is worthy of note, that the impact of this factor on premises microclimate is rather controversial. On the one hand, according to normative documents, the walls should have minimalair permeability, that provide defense from the wind of enclosure structures and reduce the heat losses. On the other hand, good air permeability gives the "breathing" walls effect, that influences on humidity level regulation in temple premises and allowsthe air to get inside and come outside through the microporous material structureand mortar joints in brick working. From this point of view, reinforced concrete walls, with air permeability approximately 2000 times less than in case of brick working, are substantially inferior to traditional construction solution.

In general, the problem of "breathing" space can be solved with someone or otherintricacies due to the intelligentmechanical ventilation design by applying ventilation equipment, which reclaims extra expenditures. Also there is a confirmed opinion about fragilityof church paintings on dry plasterat the interior surfaces of reinforced concrete walls:often, "unbreathing" paints can simultaneously lose their brightness, working together with low air permeable concrete surfaces, because of the possiblecondensateformation in condition of low steam and air permeability in connection with insufficient insulation.

The more qualified plastering and painting compositions on the mineral air permeable base can be used for lossprevention of mural painting appearance. In this matter, they can keep their original esthetical appearance for a long time in condition ofsufficient insulation and appropriate ventilation installation. In any case, the either traditional or modern exterior walls designs should be incurredby planned reconstruction.

The indoor orthodox temple space should adequate to the favorable inner acoustic requirements [9]. For this purposes, it is necessary to create the sound field diffusion. This means the equal sound spreading in temple premises, the absence of "hi-flutter echo" and sound concentration energy focuses, and sufficient time of reverberation for such types of buildings. The construction and material types have their most impact on equability of sound spreading. This is achieved by the dissection of walls surfaces, due to applied columns, niche, and others creating exterior wall plastics elements.It is common fact, that the walls details dissipate those waves from wide hearing spectrum, which are close by their leans to details geometrical dimensions.

Thus, small members in 10-20 cm dissipate higher than $1000 \mathrm{~Hz}$ frequencies, so called the "high" frequencies. The bulged applied columns with 1-2 meters width and 0,5-1 meters 
depth, and with articulation snap of 2-4 meters dissipate the frequencies in diapason at 200$600 \mathrm{~Hz}$, which are called "middle". The additive small details, the curvature, and crown of a wall divisions form allows effectively obtain dissipation of sound energy in more extent frequency range. It is obviously, from the point of view volume and planning, and construction solutions, that these wall divisions can be created more naturally while using the brick structures of exterior walls; because such structures, often, already have applying columns, which work like half-columns or pillars in wall corpus, taking up the loads from vaults and flat elements of churches roofs.

Flat concrete walls with thin construction ribs and scarcementsdissipate sound energy less well by the acoustical project and, in this case, such walls requires excessive thickness, in relation of load bearing capacity, or applying veneer from brick or gypsum plasterboards.Nonparallelity of old temple brick walls near $2-6^{\circ}$ enables to reduce multiple sound waves reflections leading to effect of "high flutter" echo and increasing the acoustic field diffusivity.It can be said that the parallel, smooth, comparatively shallow thickness reinforced concrete walls fall acoustically short of traditionally masonry walls, but not in a such high degree for severe impact on natural internal acoustics of small-scale temples.

As well as acoustic requirements to orthodox temples interiors, there are canonical requirements to their fine arts. Mural church painting at the interior surfaces, including interior walls, has it's severe laws and calls for professional approach, which is based on high quality materials application andsmart surface preparation. The type and building material of the wall often influence on dimensions and configuration of mural painting. In the view of some church painters, the brick walls surfaces are more comfortable for depiction iconographic scenes and canonical patterns. As a rule, these brick walls surfaces have a smooth vertical form transition to the vaults through the strengthened arcs and pendentives. Masonry pillars and applied columns, because of their large faces width, are more favorable for church painters, than thin structures of beams, pillars and partitions from reinforced concrete.These disadvantages can be improved by the use of veneer from brick layer or gypsum boards with a space, but that may cause rather high additional payments in case of large volume temples.

\section{Results}

The benchmark estimate of construction budget for considered walls designs variants per 1 $\mathrm{m}^{2}$ of the surface reveals the maximal cost of $1 \mathrm{~m}^{2}$ for "c" and "d" variants: near 11 and 10 thousands rubles respectively. The variant "b", combining brick working together with reinforced concrete frame, has the minimal cost. The costs of variant "a" and "b" constitute near 9 and 8 thousand rubles respectively. Exemplified cost data are fair for Moscow (the calculation was carried out by the "Federal Units Costs" document published in the year 2017 with the use of appreciation index at IV quarter of 2018 year) and reflect the specificity of pricing on materials and labor resources at Moscow region.

\section{Discussion}

Performed analyses and comparison between the traditional masonry and the contemporary reinforced concrete walls design (table 1) can't give us an unambiguous answer about advantages of the one of them. The orthodox church buildings from traditional masonry and masonry with reinforced concrete frame walls are more preferable from the point of view architectural and aesthetical designs, mural painting technology, acoustics and favor of believers. The advantages of masonry walls structures are the building material consumption and the construction budget, though their objective comparison for cost 
parameters is possible in case of complete consideration of relationship between the erection expenditures on walls and other constructions.

Table 1. Engineering, architectural and economical analyses of temple walls construction designs.

\begin{tabular}{|c|c|c|c|c|c|}
\hline \multirow[t]{2}{*}{$N$} & \multirow{2}{*}{$\begin{array}{l}\text { Thenameof } \\
\text { parameter }\end{array}$} & \multicolumn{4}{|c|}{ The variants of observed construction walls decisions } \\
\hline & & $\begin{array}{l}\text { Variant } 1 . \\
\text { Brick, } \\
\text { traditionally } \\
\text { applicated }\end{array}$ & $\begin{array}{l}\text { Variant } 2 . \\
\text { Brick, with } \\
\text { reinforced } \\
\text { concrete } \\
\text { elements }\end{array}$ & $\begin{array}{c}\text { Variant } 3 . \\
\text { Reinforced concrete, } \\
\text { with facing layerfrom } \\
\text { brick }\end{array}$ & $\begin{array}{c}\text { Variant } 4 . \\
\text { Reinforced } \\
\text { concrete, } \\
\text { with plaster } \\
\text { facing layer }\end{array}$ \\
\hline \multicolumn{6}{|c|}{ Physical, technical, and architectural properties } \\
\hline 1. & Strength & $\begin{array}{c}\text { Is achieved due } \\
\text { to large } \\
\text { thickness, } \\
\text { weight and } \\
\text { brick } \\
\text { consumption. It } \\
\text { is required more } \\
\text { wide foundation } \\
\text { band or } \\
\text { continuous } \\
\text { footing }\end{array}$ & $\begin{array}{l}\text { Is achieved } \\
\text { due to } \\
\text { reinforced } \\
\text { concrete frame } \\
\text { elements. It is } \\
\text { required less } \\
\text { volume of } \\
\text { brick }\end{array}$ & $\begin{array}{l}\text { All vertical loads are } \\
\text { taken up by the } \\
\text { reinforced concrete } \\
\text { walls. The width of } \\
\text { walls and foundations, } \\
\text { as well as their } \\
\text { weight, are less than } \\
\text { shown in the first and } \\
\text { second designs }\end{array}$ & $\begin{array}{l}\text { Similar with } \\
\text { the third } \\
\text { variant }\end{array}$ \\
\hline 2. & $\begin{array}{c}\text { Heat } \\
\text { transmission } \\
\text { resistance }\end{array}$ & $\begin{array}{l}\text { The single layer } \\
\text { wall thickness } \\
\text { from masonry } \\
\text { material is } \\
\text { sufficient, with } \\
\text { overdesign }\end{array}$ & $\begin{array}{l}\text { The single } \\
\text { layer wall } \\
\text { thickness from } \\
\text { bricks and } \\
\text { ceramic } \\
\text { blocks are } \\
\text { sufficient, but } \\
\text { matches only } \\
\text { minimal } \\
\text { thermal and } \\
\text { technical } \\
\text { norms }\end{array}$ & $\begin{array}{c}\text { There is a need in } \\
\text { effective insulation } \\
\text { (mineral wool or } \\
\text { expanded polystyrene) } \\
\text { for matching minimal } \\
\text { thermal and technical } \\
\text { norms }\end{array}$ & $\begin{array}{l}\text { There is a } \\
\text { need in } \\
\text { effective } \\
\text { insulation } \\
\text { (expanded } \\
\text { polystyrene } \\
\text { is } \\
\text { preferable) } \\
\text { for matching } \\
\text { minimal } \\
\text { thermal and } \\
\text { technical } \\
\text { norms }\end{array}$ \\
\hline 3. & $\begin{array}{c}\text { Air- and } \\
\text { steam } \\
\text { permeability }\end{array}$ & $\begin{array}{l}\text { Walls have a } \\
\text { high air- and } \\
\text { steam } \\
\text { permeability. } \\
\text { They are } \\
\text { "breathing" }\end{array}$ & $\begin{array}{c}\text { Walls have a } \\
\text { high air- and } \\
\text { steam } \\
\text { permeability. } \\
\text { They are } \\
\text { "breathing" }\end{array}$ & $\begin{array}{c}\text { Walls are not } \\
\text { practically air- and } \\
\text { steam permeable. } \\
\text { There is a risk of } \\
\text { condensate formation } \\
\text { and early inner mural } \\
\text { demolition. } \\
\text { It should be high- } \\
\text { powered ventilation } \\
\text { system }\end{array}$ & $\begin{array}{l}\text { Similar with } \\
\text { the third } \\
\text { variant }\end{array}$ \\
\hline 4. & $\begin{array}{c}\text { External } \\
\text { decoration } \\
\text { (architectural } \\
\text { millworks } \\
\text { and facade } \\
\text { relief } \\
\text { effects) }\end{array}$ & $\begin{array}{c}\text { Comparatively } \\
\text { simple } \\
\text { architectural } \\
\text { millworks and } \\
\text { compositional } \\
\text { facade } \\
\text { articulations } \\
\text { due to the } \\
\text { blooming or } \\
\text { figured brick } \\
\text { working }\end{array}$ & $\begin{array}{l}\text { Similar with } \\
\text { the first } \\
\text { variant }\end{array}$ & $\begin{array}{l}\text { It is required the } \\
\text { boosting of external } \\
\text { facing layer, due to its } \\
\text { high thickness } \\
\text { because of } \\
\text { architectural } \\
\text { decoration. Low } \\
\text { constructability of } \\
\text { external layer in case } \\
\text { of possible insulation } \\
\text { replacement under }\end{array}$ & $\begin{array}{l}\text { The frequent } \\
\text { full repairs } \\
\text { for plaster } \\
\text { recovering } \\
\text { and tinting } \\
\text { at facade } \\
\text { surfaces, } \\
\text { including } \\
\text { separate } \\
\text { decorative } \\
\text { elements }\end{array}$ \\
\hline
\end{tabular}




\begin{tabular}{|c|c|c|c|c|c|}
\hline & & & & reconstruction & $\begin{array}{c}\text { from } \\
\text { expanded } \\
\text { polystyrene, } \\
\text { are possible }\end{array}$ \\
\hline 5 . & $\begin{array}{c}\text { Temple } \\
\text { interior } \\
\text { acoustics }\end{array}$ & $\begin{array}{c}\text { Naturally } \\
\text { created internal } \\
\text { temple surfaces } \\
\text { articulations for } \\
\text { sound field } \\
\text { diffusivity }\end{array}$ & $\begin{array}{c}\text { More } \\
\text { intricately } \\
\text { created } \\
\text { internal } \\
\text { temple } \\
\text { surfaces } \\
\text { articulations } \\
\text { for sound field } \\
\text { diffusivity in } \\
\text { comparison } \\
\text { with first } \\
\text { variant }\end{array}$ & $\begin{array}{l}\text { Less favorable } \\
\text { conditions for sound } \\
\text { field diffusivity } \\
\text { creation because of } \\
\text { multiple } \\
\text { perpendicularly } \\
\text { crossing surfaces. It } \\
\text { may become } \\
\text { necessary an additive } \\
\text { veneer and detailing } \\
\text { of surfaces from } \\
\text { gypsum board. }\end{array}$ & $\begin{array}{l}\text { Similar with } \\
\text { the third } \\
\text { variant }\end{array}$ \\
\hline 6. & $\begin{array}{c}\text { Usable } \\
\text { surfaces for } \\
\text { mural } \\
\text { painting }\end{array}$ & $\begin{array}{l}\text { Walls surfaces } \\
\text { are well suitable } \\
\text { for traditional } \\
\text { Bible subjects } \\
\text { depiction }\end{array}$ & $\begin{array}{c}\text { Walls surfaces } \\
\text { are less } \\
\text { suitable for } \\
\text { traditional } \\
\text { Bible subjects } \\
\text { depiction, than } \\
\text { in first variant }\end{array}$ & $\begin{array}{l}\text { Wall surfaces and thin } \\
\text { pillars and separation } \\
\text { walls facets can cause } \\
\text { the traditional Bible } \\
\text { subject and } \\
\text { ornamental schemes } \\
\text { changing. The } \\
\text { additive curvilineal } \\
\text { gypsum slab } \\
\text { coverings and closures } \\
\text { can be required }\end{array}$ & $\begin{array}{c}\text { Similar with } \\
\text { the third } \\
\text { variant }\end{array}$ \\
\hline \multicolumn{6}{|c|}{ Cost indicators } \\
\hline 7. & $\begin{array}{c}\text { Construction } \\
\text { budget of } \\
\text { wall's } 1 \mathrm{~m}^{2}, \\
\text { including } \\
\text { materials }\end{array}$ & $\begin{array}{l}8956,84 P \\
6593,5 P\end{array}$ & $\begin{array}{l}7816,87 P \\
5683,1 P\end{array}$ & $\begin{array}{l}11108,16 P \\
8249,05 P\end{array}$ & $\begin{array}{c}10055,89 P \\
7408,63 P\end{array}$ \\
\hline
\end{tabular}

Also the specificity of site region and building activities pricing should be taken into account, because the costs of materials and labor forces can be substantially various in different areas of Russia.

\section{Conclusions}

As for the author's opinion, large scale cultural buildings (cathedrals, monastic temples) are rational to be build from masonry brick materials, maybe, with the use of wall reinforced concrete frame elements. Other types of temples can be build with the reinforced concrete walls application accordingly the site conditions.

It stands to mention, that contemporary orthodox temple architecture moves beyond only application of the observed in this article walls structures; for instance, today the wooden and quickly erected modular buildings are actively designed. Perhaps, the researching of these cultural orthodox architecture directions will be included in the authorsscope of interests in future.

\section{References}

1. A.A. Kuz'menkov, S.A. Titova, Resources and Technology 13(4), 57-70 (2016) DOI: 10.15393/j2.art.2016.3481 
2. A. Ivashchenko, S. Titova, StudArctic Forum 4(8), 46-50 (2017) DOI: 10.15393/j102.art.2017.1961

3. I. Saltykov, M. Bovsunovskaya, IOP Conf. Series: Earth and Environmental Science 90, 012173 (2017) doi :10.1088/1755-1315/90/1/012173

4. M. Bovsunovskaya, I. Saltykov, MATEC Web of Conferences 265, 107028 (2019) https://doi.org/10.1051/matecconf/201926507028

5. N.A. Kasatkina, The scientific potential of the regions on the service of modernization, AISI, 33-40 (2011)

6. S.V. Borisov, M.L. Bagdasarian, Privolzhskiy nauchniy vestnik 7(47), 31-34 (2015)

7. S.N. Eremeev, Journal of Construction and Architecture 1, 60-73 (2019) https://doi.org/10.31675/1607-1859-2019-21-1-60-73

8. M. Kesler, Education and Orthodoxy, ZHMP 6 (2015)

9. K. Kosała, P. Małecki, Applied Acoustics 130, 140-148 (2018) https://doi.org/10.1016/j.apacoust.2017.09.015 